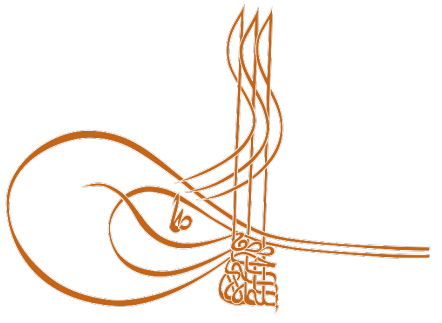

www.turkishstudies.net/language
Turkish Studies - Language and Literature

eISSN: $2667-5641$

Research Article / Araștırma Makalesi

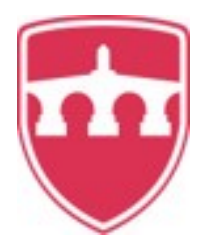

INTERNATIONAL

BALKAN

UNIVERSITY

Sponsored by IBU

\title{
Safahat'ta Toplumsal Göndergeleriyle Uyku Metaforu ve Mehmet Âkif Ersoy'un Uyan Şiirinin Tahlili
}

Sleep Metaphore with Social References in Safahat and Analysis of Akif's "Uyan" Poem

\author{
Gürhan Çopur ${ }^{*}$
}

\begin{abstract}
In literary texts, the metaphors of sleep / wakefulness are mostly made visible as a warning to the individual / society, whose mind and vital reflexes have been sterilized and have given up the struggle. When an individual or society loses a certain level of consciousness, ontological sense, they experience a decline in sleep. This state of sleep has been described in many works as a reflection of collective consciousness throughout the historical process of Turkish literature. These values are seen as the whole of the building blocks that constitute the religious and national atmosphere of the poet's self. Mehmet Âkif Ersoy's poems are based on the values that create the society in which he belongs. In the poetry of Âkif, the metaphor of sleep and wakefulness takes place at the social level with the intense criticism by taking place within the framework of the concepts of perception, lack of consciousness, loss of struggle and struggle. However, these texts come up with an action-oriented view of national romantic perception and solution suggestions that precede the idea of progress. This social criticism, which is observed intensely in Safahat, can also be perceived as the activating element of the path of salvation, in which Akif leads with great effort. The poet, who criticizes the green and sleep state of the society with a high intonation, defines the dilemma in which society exists by establishing his work in the triangle of past, state and future. In this study, the sleep metaphor, which is found as a malicious feature in Mehmet Akif Ersoy's poetics, will be outlined in general lines; The poet's poem "Wake Up", which focuses only on this point and has a stimulating structure against the society, will be examined with the vertical dimensions of the symbols and representational values in the social sense.
\end{abstract}

Structured Abstract: The depiction of society in Safahat not only reflects malfunctions from a realistic perspective, but also includes warnings of intellectual consciousness. Always struggling on social issues by getting one step forward, Âkif unifies its solution suggestions to the problems it diagnosed within Safahat. This sentence, written by Orhan Okay for Safahat, clarifies the subject; "It is the depiction of the community on the revelation table." (Okay, 2017: 40). In Safahat, the material and spiritual diseases of the society have been determined by the poet, and solution suggestions of the disease and problems have been given; it has also been aimed to bring the society home to it through harsh warnings if necessary. Safahat, in which the collective

\footnotetext{
* Dr., Ardahan Üniversitesi, İnsani Bilimler ve Edebiyat Fakültesi, Türk Dili ve Edebiyatı Bölümü, Yeni Türk Edebiyatı, PhD., Ardahan University, Faculty of Humanities and Literature, Department of Turkish Language and Literature, Contemporary Turkish Literature ORCID 0000-0002-6854-005X gurhancopur@gmail.com
}

Cite as/ Atıf: Çopur, G. (2020). Safahat'ta toplumsal göndergeleriyle uyku metaforu ve Mehmet Âkif Ersoy'un Uyan şiirinin tahlili, Turkish Studies - Language, 15(1), 121-130. https://dx.doi.org/10.29228/TurkishStudies.40518

Received/Geliș: 11 January/Ocak 2020

Accepted/Kabul: 25 March/Mart 2020 Checked by plagiarism software

Copyright à INTAC LTD, Turkey Published/Yayın: 30 March/Mart 2020 CC BY-NC 4.0 
memory of and social values of the Muslim Eastern society are located together, is beyond any composition of poems because it can be described as a sound of the set of values, awareness and sensibility that create the society often found in the works of the poet. With the features of the characters and the thematic structures of its poems, Safahat has appeared as the product of an intellectual consciousness that aims to arouse the Muslim Eastern society through a critical perspective. His poem, based on these principles, where he places his individual and social identity, addresses the society in general. The criticism of Âkif, who takes social issues into his works with the restlessness and anxiety of an intellectual consciousness, is constructive but it is strongly directed to his interlocutor. In this regard, Âkif tries to steer the society with its works that it places a stimulating task by taking its reader to the center, and offers its solutions with an innovative structure. Analyzing the Ottoman society with a holistic eye, the Âkif makes its findings visible with history, which is the most important element in the establishment of the present, and with the concept of lesson as one of the important stimuli of history. As seen throughout Safahat, his poems, which analyze the society and the state institutions with a successful observation, are not content with observation, embody the critical dimension which has a function to call for action, and include the rebellion of the poet for the era in which he was born. This rebellion was commented by Nurettin Topçu; "this rebellion movement is a completely opposite to the rebellion movement that rises with exasperation or weariness, or ambitions of domination and superiority for many people." (Topçu, 2011: 82). This rebellion, which is initiated with a sense of responsibility towards the society and a sense of intervention in the malfunctions, not only stands out as an idealistic and intellectual belief at a point far from the usual riot definitions because of being far from individuality, but also it is seen as a whole of actions that does not contain frustration, interests, hatred and arrogance which arise with the reference of belief systems.

The biggest problem he sees in the Muslim Eastern society, which Âkif is involved and defines with a holistic observation, is the state of woolgathering. The state of woolgathering gains concreteness with the loss of problem that encompasses all the areas of value that set the individual in ontic sense, such as insensitivity to current issues and despair, bigotry, aimlessness, immobility, rottenness, incompetence, ignorance that completely surrounded the Islamic world. During his life, Akif worries about the situation described in the following sentence; "the fact that the Islamic world is surrounded by various evilnesses and especially the public has lost hope in everything" (Bilgegil, 1980: 437). While determining and analyzing these diseases of the society, Mehmet Âkif mostly refers to religious resources and and especially to the Quran that shape his life. By depicturing the ideal human type determined by the religion of Islam from the Qur'an, he gives the example of this type of human to his interlocutor. Âkif, who uses the mind, does not imprison religion in a bigotry, absorbs the knowledge of the era and is longing for a patriotic individual, is the enemy of inattention, woolgathering and despair and these are ones which the poet underlines and offers solutions by referring to the religious sources. While presenting these suggestions, Âkif prioritizes mind, science, human values and modernity. In this sense, embracing these concepts without any religious or national extremism is an important tool to move the society forward.

The individual's cognitive state of alertness is his unique armor that will keep him away from evil and protect him from danger. The generations grown up by the cultural resource, which has a great heritage, live without knowing the past, without fiction of the future and also unaware of the dangers of the present. The process witnessed by Âkif is a period in which the society and the state were trapped in a great tragedy and their defense mechanisms were paralyzed. With the metaphor of woolgathering, it is aimed to stimulate the society with vital reflexes and provoke to bring the society home to it. This metaphor, which is frequently used in Safahat, is one of the most important elements of a composition that aims to call for salvation and resurrection.

The poet, who criticizes social diseases such as woolgathering and loss of problems in his poetry in which we examine it, completes his criticisms with solutions. Exhibiting the problems with the awareness of the intellectual consciousness by summarizing the period and the social orientation of the period, the poet aims to attract attention with his discourse that aims to raise awareness and to be stimulating by preserving his style that can be seen throughout Safahat. Desiring to revive and wake up with the return to the roots and religious values against the loss of self-confidence and loss of problems faced by the society, the poet builds the whole work by being faithful to the values system of the society he deals with. The poetry, which can be considered as a summary of the poetics of Mehmet Akif Ersoy, is a work that stands out in the social aspect by weaving it with vertical messages of woolgathering, problem loss, consciousness paralysis and lack of self-confidence.

Turkish Studies - Language, 15(1) 
Keywords: Turkish Language and Literature, Poem, Sleep state, Safahat, Mehmet Âkif Ersoy, Uyan.

Öz: Edebî metinlerde uyku/uyanıklık metaforları çoğunlukla zihnî ve yaşamsal refleksleri kısırlaşmış, mücadeleden vazgeçmiş bireye/topluma karşı uyarı olarak yer alır. Birey ya da toplum kendisini var eden ve tehlikelere karşı korunaklı kılan değerler dizgesinin bütünü olan bilincini kaybettiği zaman, ontik bağlamda düşüş yaşar. Yok edici etikileri olan bu durum metaforik anlamda bilinç kapalılığ 1 ya da uyku hâli olarak değerlendirilir. Bu uyku hali, Türk edebiyatının tarihsel süreci boyunca kolektif bilincin inşasında yoğun olarak kullanılmış ve hastalıklı görüngüler bütününü üstüne toplamış bir öge olarak sunulmuştur. Mehmet Âkif Ersoy’un şiirleri üyesi olduğu toplumu var eden değerler üzerine konumlanır. Bu değerler, şairin poetik tavrının dini ve millî atmosferini oluşturan yapıtaşlarının bütünü olarak görüntü bulur. Âkif'in şiirinde uyku ve uyanıklık metaforları toplumsal düzeyde idrâk, miskinlik, problem yitimi ve mücadele kavramları çerçevesinde yer alarak yoğun bir içerikle var olurlar. Bununla birlikte bu metinler millî romantik duyuşla, terakki fikrini önceleyen, çözüm önerilerini eylem odaklı bir bakışla var eder. Safahat'ta yoğun bir biçimde gözlemlenen toplumsal eleştiri, aynı zamanda Âkif 'in büyük bir gayretle yöneldiği kurtuluş yolunun harekete geçirici unsuru olarak da algılanabilir. Yüksek bir tonlamayla toplumun umutsuzluk ve uyku halinin eleştirisini yapan şair, beraberinde geçmiş, hâl ve gelecek üçgeninde eserini kurarak toplumun içerisinde bulunduğu açmazı anlatır. Bu çalışmada Mehmet Âkif Ersoy’un poetikasında karşıt değer olarak yer alan uyku metaforu genel çizgileriyle belirtilecek; şairin yalnızca bu noktaya odaklanan ve topluma karşı uyarıcı bir yapıda olan "Uyan" adlı şiiri, toplumsal anlamdaki sembolleri ve temsil değerlerinin dikey boyutlarıyla irdelenecektir.

Anahtar Kelimeler: Türk Dili ve Edebiyatı, Şiir, Uyku hali, Safahat, Mehmet Âkif Ersoy, Uyan.

\section{Giriş: Teşrih Masasındaki Cemiyet ya da Safahat'ta Toplum Eleştirisi}

Safahat'taki toplum tasviri realist bir bakış açısıyla aksaklıkları yansıtmanın yanında kolektif şuuru kuşanmıș aydın bilincinin uyarılarını da içerir. Toplumu ve devleti ilgilendiren konularda her zaman bir adım öne çıkan ve mücadele içerisinde yer alan Âkif, teşhis ettiği sorunlara çözüm önerilerini estetik ifadenin imkânları ve sosyal gözlemler çerçevesinde Safahat'ta bütünleştirmiştir. Orhan Okay'ın Safahat için kullandığı; “cemiyetin teşrih masasındaki tasviridir.” (Okay, 2017: 40) tespiti bu vurguyu açıkça ifade eder. Toplumun maddi ve manevi hastalıkları benliğinde kolektif ruhu taşıyan şair tarafından teşhis edilmiş, eser içerisinde hastalığın ve problemlerin çözüm önerileri sunulmuş; ayrıca gerekli görülen yerlerde ağır eleştirilerden kaçınmayarak muhatabın kendine gelmesi amaçlanmıştır. Müslüman Doğu toplumunun kolektif hafızası ve toplumsal değerlerinin bir bütün olarak yer aldığ 1 Safahat, şiirlerden oluşan bir terkipten daha ötede, toplumu var eden değerler dizgesinin, farkındalığın ve duyarlılığın şairin eserlerinde ses bulmuş hali olarak tarif edilebilir. Âkif'in bilinçli bir şekilde oluşan bu yönelimini Sebilürreşad dergisindeki bir makalesinde şöyle ifade eder; 'Şiir için, edebiyat için 'süs', 'çerez' diyenler var. Karnı tok, sırtı pek milletlere göre bu söz belki doğrudur. lâkin bizim gibi aç, çıplak milletlere süsten, çerezden evvel giyecek, yiyecek lazım. Onun için ne kadar süslü, ne kadar tatlı olursa olsun, libas hizmetini, gıda vazifesini görmeyen edebiyat bize hiçbir şey söylemez." (Ersoy, 1912: 10). Safahat, kurgusunda yer alan karakterleri ve izlekleriyle Müslüman Doğu toplumunu eleştirel bir bakışla harekete geçirme amacı güden bir aydın bilincin ürünü olarak karşımıza çıkar. Bireysel ve toplumsal kimliğini konumlandırdığı bu prensipler üzerine inşa ettiği şiiri, genel itibariyle topluma seslenir. Bu sesleniş terkibi; "İslâm dünyasının toplumsal durumunu anlamada öncelikli bir kaynak olarak durmaktadır." (Alver, 2008: 351). Öncelikli toplumsal bir kaynak olarak tanımlanan gerçeklik, Safahat'ın girişinde okurlara hitaben yer alan; "Bir yı̆̆ın söz ki, samimiyeti ancak hu $\square$ neri; Ne tasannu bilirim çu $\square$ nku $\square$ ne sanatkârım." (Ersoy, 1999: 3) dizelerinde karş1lık bulurken şairin de poetik hassasiyetini yansıtmış olur. Bu ifade ile aynı zamanda idealize edilmiş yüksek ahlâk ve terakki fikirleri çerçevesinde şekillenen bir düşünceyi somut kılar. Âkif, geçmiş ve şimdinin hakikatini bütünlük içerisinde, topluma ve 
toplumsal olana dikkat kesilerek estetik bir dille okuruna sunar. Böylelikle onun şiiri, döneminin panoraması olma özelliğini de kazanır. Safahat'ın tamamına yayılan, sosyal gerçeklik ve şairin bu konudaki tavrını Mehmet Kaplan şöyle belirtir; "Türk edebiyatında onun kadar içinde yaşadığı devri bütün teferruatı ile gören ve gösteren başka bir şair yoktur denilebilir.” (Kaplan, 2003: 174). Kaplan, realist ve toplumsal yönüne vurgu yaptığı değerlendirmesinde Âkif' in gözlem yeteneğini yüksek bir derecede görür. Toplumsal konuları aydın bir bilincin taşıdığı huzursuzluk ve kaygıyla eserlerine alan Âkif'in eleştirileri de; yapıcı anlamda olmakla birlikte şiddetli bir şekilde muhatabına yönelir. "Okur merkezli bir aktarımın hedeflendiği Âkif manzumelerinde, hissetme, hissettirme, sezdirme, uyarma işlevi dikkat çeker. Eserde Müslüman Türk kültüründe insanın kendini yenileme edimi özgün bir dönüşüm içinde kurgulanır. Öznel çözülmeyi engellemek yönünde çağrı yapan metinler toplamı olan Safahat'ta öze dönüş olanaklarının anlatımları sunulur." (Eliuz, 2016: 69). Bu bakımdan Âkif, okurunu merkeze alarak uyarıcı bir görev yüklediği eserleriyle topluma yön vermeye çalışmakla birlikte çözüm önerilerini de yeniliği merkeze alarak sunar. Osmanlı toplumunu bütüncül bir gözle tahlil eden Âkif, tespitlerini hâlin kuruluşundaki en önemli unsur olan tarihle ve ibret kavramıyla görünür kılar. Safahat genelinde görüldüğ̈̈ gibi toplumu ve devlet kurumlarını başarılı bir gözlemle tahlil eden şiirleri, gözlemleme ile yetinmez ve harekete çağrı niteliğinde olan eleştirel boyutu da somut kılar ve şairin, içerisine doğduğu çağına isyanını barındırır. Bu isyan Nurettin Topçu'nun yorumuyla; "birçok insanlarda taşkınlık veya bezginlikle veyahut tahakküm ve üstünlük hırslarıyla yükselen isyan hareketinden tamamen başka, hem de onlara zit bir harekettir.” (Topçu, 2011: 82). Toplumsal düşünce katmanına erişen ve düşünsel aksaklıklara yönelen bu isyan, inanç dizgelerinin referansıyla gerçekleşen ve hüsran, menfaat, kin ve kibir barındırmayan bir eylemsellikler bütünü olarak gerçekleşir. Eserlerindeki isyanla harmanlanmış olan bu eleştirel tavrın sebepleri, Kâzım Yetiş'in; "onun şiiri harap, perişan hâldeki, bitik, maddeten manen çökmekte olan bir toplum, bir vatan için ağıttır." (Yetiş, 2006: 84) tanımlamasıyla netleşir ve şairin sesindeki yüksek tonun sebebi daha açık bir hâle kavuşur. Toplumsal değerleri önceleyen bir duyarlılığa sahip olan şair de poetikasını kendi sesini aldığı toplumunun ihtiyaçları çerçevesinde oluşturacaktır.

\section{Müslüman Doğu'nun Büyük Hastalığı: Uyku Hali/Problem Yitimi}

Âkif'in dâhil olduğu ve bütüncül bir gözlemle tanımladığı Müslüman Doğu toplumunda gördüğü en büyük problem, uyku hâlidir. Söz konusu uyku hâli, güncel meselelere karşı duyarsızlık, ümitsizlik, taassup, amaçsızlık, hareketsizlik gibi, bireyi ontik anlamda kuran, tüm değer alanlarını yok eden problem yitimiyle somutluk kazanır. Toplumun uykusunun bilinç katmanındaki çözülmeye işaret eden varyasyonları başta Dede Korkut Kitabı, Kutadgu Bilig, Divan-1 Hikmet gibi Türk kültürünün önemli eserlerinde mitik özelliklerle yer alır. Tanzimat ile başlayan modernleşme ve aydınlanma atılımının etkisiyle görünürlüğ̈̈ artar; özellikle ikinci meşrutiyet kalemlerinin millî kimliği önceledikleri eserlerinde zirveye çıkar. Bu bilgiler ışığında, millî romantizmi kendi şahsında ve değerler dünyasında sentezleyen Âkif'in poetik birikiminin önemli noktalarını Türk edebiyatının çeşitli safhalarıyla da görmek mümkün olur. Yaşadığı dönemde gözlemlenen; "İslâm âlemini çeşitli fenalıklar sarmış [olması] ve bunların başında halkın her şeyden üm'idi kesmiş olması”" (Bilgegil, 1980: 437) durumu Âkif'i kaygılandırır. Âkif, kaygılarının çözümünü bulmak için terakki yolunu tutmanın yanında yaşamını şekillendiren dini kaynaklara ve bunların en başında da; "Feyz aldı cihan senin yüzünden, Bir bârika-i kemâlsin sen" (Ersoy, 1999: 556) dediği Kuran-ı Kerim'e başvurur. İslâm dininin belirlediği ideal insan tipini "Kuran-1 Kerim"den hareketle eserlerinde canlandırarak muhatabına bu insan tipinin örneğini de vermiş olur. Aklını kullanan, dini bir taassup içerisine hapsetmeyen, çağın teknolojik ve ruhi gelişimini özümsemiş ve vatansever bir birey özleminde olan Âkif' in düşman olduğu uyku, gaflet ve ye's hali, şairin kutsal kaynaklara atıfta bulunarak belirttiği ve çözüm yollarını sunduğu problemlerden en önemlileridir. Âkif, bu önerilerini sunarken aklı, bilimi, insani değerleri ve çağdaşlığı önceler. Hakkında yazılan birçok çalışmada da görülebileceği üzere terakki fikrini Batı'ya yetişmenin anahtarı olarak sunan Âkif, kendilik değerlerini muhafaza etmek koşuluyla Batı'yı takip etmekte bir sakınca görmez. Öyle ki sanat ve bilim, sınırlandırıcı ve 
kısırlaştırıcı bağnaz fikirlere sığdırılamayacak kadar geniş ve insanlığın tümüne ait kavramlardır. Bu anlamda herhangi bir aşırıllı̆a kapılmadan bu kavramları sahiplenmek toplumu ileriye taşıyacak önemli araçlardır.

Bireyin bilişsel anlamdaki uyanıklık hali, kendisini kötülüklerden uzak tutacak ve tehlikeden koruyacak biricik zırhıdır. Yaşamın getirdiği kötücül etkiler ve trajedilere karşı tetikte olmayı sağlayan bu zırh, ontik anlamda varlığının farkında olan ve tarihselliğini hâl ile harmanlamış bireylerin/toplumların hayati öneme sahip korunakları olur. Büyük bir mirası barındıran kültür kaynağının yetiştirdiği nesiller, geçmişini bilmeden, geleceğe dair kurgudan yoksun ayrıca hâlin tehditlerinden habersiz yaşamaktadırlar. Âkif' in şahit olduğu süreç, toplumun ve devletin büyük bir trajedi içerisinde kalakaldığı, savunma mekanizmalarının felce uğradığı bir dönemdir. Uyku metaforu ile yaşamsal refleksleri körelmiş toplumu uyarmak ve kendine dönmesi için tahrik etmek amaçlanır. Safahat'ta sıklıkla kullanılan bu metafor, kurtuluşa ve yeniden dirilişe çağnı amacını taşıyan bir terkibin en önemli unsurlarından biri olarak karşımıza çıkar.

Yine Mehmet Âkif, Süleymaniye Kürsüsü'nde Abdürreşid İbrahim'in ağzından;

"Sizi kim kaldıracak, sûru mu İsrâfil'in?

Etmeyin!... Memleketin hâli fenalaşt1... Gelin!” (Ersoy, 1999: 183)

sesleniş̧iyle, Müslüman Doğu toplumunun uyku halinden uyanmasını ve harekete geçmesi arzusunu belirtecektir. Vatanın selameti konusunda var olan ciddi tehlikelere dikkat çeken şair, toplumun harekete geçmesinin, kıyamet gibi geri dönüşü olmayacak bir anda son ve faydasız bir hamleyle mi gerçekleşeceği sorusunu bir soru cümlesiyle topluma yöneltir. Sizi kim kaldıracak ve etmeyin uyarıları sert bir üslupla muhatabını tahrik ederek dikkatini üst noktalara taşıma amacı güder. "Âkif'in cemiyetimizde müşahede ettiği esas nokta, her sahada kendini gösteren geriliktir." (Timurtaş, 1987: 79). Bahsedilen gerilik, Âkif' in düşünce dünyasında düşünsel ve ortak değerler bütününü içten içe çürüten ve toplumu algıları ve tepkileri yitmiş bir kalabalığa dönüştüren tehlikeli bir hastalık olarak görülmektedir. Problem yitimine uğramış toplumlar, özelden genele doğru ilerleyen savunma içgüdülerinden sıyrılmış, yalnızca içerisinde bulundukları kısır daire içerisinde bir ömür sürmektedirler. Bireysellikten toplumsallığa uzanan ontolojik bir kurgu dâhilinde hiçbir çabası ve düşüncesi olmayan bireyler, ülkenin içerisinde bulunduğu tehlike ve tehditleri de algılayamayacak kadar körelmiş bir alg1 içerisinde yaşarlar. Bu körlük, yaşamsal anlamda bireyin en önemli reflekslerinden olan kaygıyı da yok edecektir. "Oysa kaygı, ontolojik anlamda insanı kuran bir itkidir; bireyin ve toplumların geleceğini biçimlendirir. Kaygılarını yitiren birey ve toplumlar gelecek tasarımlarını da yitirirler." (Korkmaz, 2011: 17). Bu bakımdan kaygı, Korkmaz'ın da bahsettiği gibi bireyi ve toplumu ontolojik anlamda kuran, tehlikelere karşı koruyan yaşamsal bir öneme sahiptir. Kaygısını kaybeden toplumlar gelecek planlamasında edilgen bir yapıya bürünürler. Âkif' in karşı çıtığı uyku hali de bu türden ölümcül kaygı yitimine işaret eder. Safahat'ın geneline yayılan bu uyarıcı üslup, toplum karşısında şairin kendisine yüklendiği önemli bir vazifedir. Âkif, yine Asım'da;

"Sonra dört yüz bu kadar milyon adam, hepsi cebin!

Şark'a in, Mağrib'e yüksel göremezsin galeyan...

Nasıl olmuş da uyuşmuş bütün ümmetteki kan?” (Ersoy, 1999: 422)

diyerek toplumun kanında meydana gelen uyuşma olarak tanımladığı tepkisizliğin, dört yüz küsur milyon insanı birer korkak(cebîn) haline getirdiğini söyler. Müslüman Doğu toplumunun hareketsiz ve tepkisiz kalışına karşı yöneltilen ağır bir eleştiri olan cebin / "korkak"lık, şair tarafından hayretle karşılanmaktadır.

Safahat'in neredeyse tamamında bireysel konulara bilinçli olarak mesafeli durarak poetikasını toplumsal konular üzerinden var eden Âkif, şiirinin konusunu da toplumun ve devletin 
içerisindeki durumu göz önüne alarak belirler. 1915 yılı Osmanlı Devleti’nin yaşadığı trajik çöküşün en kanlı yıllarından birisidir. Âkif, Afrika'daki toprak kayıpları, Balkan hezimeti ve süregelen yıkım içerisindeki Osmanlı toplumuna sirayet eden özgüvensizlik, algısal körlük ve problem yitimine karş1 Uyan şiiriyle topluma âteşîn bir tavırla haykırır. Şiirin başlığı da eserin izleksel kurgusunun merkezi vazifesini görmektedir. Zeki Sarıhan'ın 1915 yılının; "Şubat başında da Müslümanları savaşmaya çağıran bir manzumesi yayımlanmıştır." (Sarıhan, 1996: 67) cümlesiyle hakkında bilgi verdiği Uyan adlı şiir, Safahat'ın Hatıralar bölümünde yer alır.

\section{Aydın Bilincin Topluma Çağrısı: Uyan!}

Osmanlı Devletinin içerisinde bulunduğu süreci gözlemlemekle birlikte, aydın bilinciyle yaklaşan büyük yıkımı ve kaosu fark eden Âkif, karşısında duran zihni ve sosyal değerleri çözülmüş kalabalığı uyarmak, harekete geçirmek ister. Karşısındaki taassup ve kadercilik sarmalında hissizleşen toplumu yeniden kurmak, akılcı ve geçmiş-gelecek dizgesi etrafinda yeniden harekete geçirmek isteyen şair, bu fikrini Uyan şiirinde yüksek perdeden işleyecektir:

"Baksana kim boynu bu $\square \mathrm{ku} \square \mathrm{k}$ ağlayan?

Hakk-1 hayâtın senin ey mu $\square$ slu $\square$ man!

Kurtar o bîçâreyi Allah için,

Artık ölu $\square$ m uykularından uyan!” (Ersoy, 1999: 306).

Uyan şiiri, muhatabına emir kipiyle seslenen "baksana” ünlemiyle başlar. Bu ünlem/sesleniş, toplumun bilinç düzeyini hedef alan, uyarıcı ve kuşatıcı bir ifadedir. Hâl'in tehlikesini sezmiş ve idrak etmiş olan şair, toplumun içerisinde bulunduğu zihinsel uyku hâline gönderme yapar. Âkif'in bu yüksek perdeden haykırış1; kültürel ve manevi değerleri kuşanarak kendini yeniden kuran/var eden bir toplum özleminin sesidir. Bu açıdan Şerif Aktaş'ın da belirttiği gibi Âkif; "gözleri sürdürülen hayatın problemlerinde, gönlü kurulacak müreffeh hayatta, İslâmî değerlerin aslına bağlı, gerçek anlamda millî romantik bir şahsiyettir.” (Aktaş, 2005: 193) Safahat içerisinde yoğun olarak görülebilecek bu duyuş, şairin dünyayı algılayışının ve karakterinin de önemli bir parçasıdır. Bir sonraki dörtlükte geçen; Bunca zamandır uyudun kanmadın; Çekmediğin kalmadı, uslanmadın dizeleriyle ölüm uykusu olarak tanımladığı uyku halinin ontik anlamdaki kaygı yitimini ve toplum düzeyindeki iradesizliği bir kere daha vurgular. Birey, geçmiş ve gelecek arasındaki nedensellik bağ ve yaşanmışlıklardan ders alma yetisini kaybettiğinde ölümcül bir farkındalık yitimine uğrar. Farkındalığını yitirmiş kalabalıklar uçuruma koşan bir sürü gibi telaşlı ve bilinçsizdirler:

"Ninni değil dinlediğin velvele...

$\mathrm{Ku} \square$ kreyerek akmada mu $\square$ stakbele,

Bir ebedî sel ki zamandır adı;

Haydi katıl sen de o coşkun sele.” (Ersoy, 1999: 306)

Kader karşısında edilgen bir yapıda olan toplum, geleceğin kurgusu ve yarını var etmek için harekete geçme konusunda hep başkasının atılımını beklemekte, bir yönlendirici aramaktadır. "Haydi!" haykırışıyla yüksek bir tonlamayla toplumu kendi iradesi ve isteği ile harekete geçirmek isteyen Âkif, toplumun karşısına akışkanlığı ve geri dönülemezliği temsilen zamanı örnek olarak koyar. Batı karşısında siyasi üstünlüğünü kaybetmekle birlikte toplumsal anlamda büyük bir çözülüşe maruz kalan Osmanlı ve İslâm toplumu bu uyarının muhatabıdır. Dönem perspektifinde uyku/problem yitimi halinden kurtulamayan toplum, velvele halinde yaklaşan belayı bir ninni sükûnetiyle algılamaktadır. Âkif, bir çözüm önerisi, yaşamsal bir atılım gerçekleştirmeyen topluma karşı zaman adlı coşkun sel'e katılması ve yeniden kendine dönmesi konusunda uyarılarda bulunur. Bir sonraki dörtlükte dalgaların seyrini anlamadan girdaba bile bile kapılmanın sonunun helak olmak gibi yok edici bir şekilde sonlanacağını anlatan şair, "Göz göre göre girdaba nedir inhimak?” (Ersoy,

Turkish Studies - Language, 15(1) 
1999: 306) diye soracaktır. Geçmişin acı tecrübelerinden ders alınması gerekliliğini belirten şair, yaşamsal anlamda gereklilik teşkil eden bu eylemi kaygılı ve şiddetli bir tonda haykırır:

"Dehşet-i mâzîyi getir yâdına;

Kimse yetişmez yarın imdâdına.

Merhametin yok diyelim kendine;

Merhamet etmez misin evlâdına?" (Ersoy, 1999: 306).

Toplumlar, geçmişleriyle var olurlar. Bu bağlamda kolektif hatıraların bir bütünü olan toplumsal belleğe göndermede bulunan şair, "ben'lerini kaybeden umutsuzlar" (Kierkegaard, 2010: 50) topluluğu haline dönüşen toplumu, tarihsellikle yeniden canlanmaya çağırır. Osmanlı coğrafyasında yaşanmış olan zulüm ve faciaları anımsatarak bir başına kalmış toplumu kendilik değerleri etrafında yeniden dirilişe davet eder. Âkif, burada geçmişi şimdiyle buluşturan problematik bir bilinç kimliğinin kolektif sesi olur. "Kişinin kendini çevreleyen şeyler dünyasında yitip gitmemesi için onun, tarihselliğini sağlayan bellek mekânlarına tutunması ve orada kurduğu kendilik bilinci ile hem uzamsal boyutta dünya ile hem de zamansal boyutta toplumsal geçmişiyle bağlantıya geçmesi kaçınılmaz bir gerekliliktir." (Korkmaz, 2008: 31). Dehşet-i mazi ile ifade edilen tarihsel yaşanmışlıklar örüntüsünün, Balkan Savaşları'na bir gönderme olduğu düşünülebilir. Bu göndergeler, toplumla eşzamanlı ilerleyen zamanın içerdiği ve onunla birlikte var olan olumlu hatıraların yanında; yıkımları, yitimleri ve hataları da içermektedir. Dolayısıyla şair, topluma, Korkmaz'ın deyimiyle hem uzamsal hem de zamansal boyutta geçmişten ders alınması gerekliliğini aktarır. Toplumun belleğini oluşturan ve onlarla birleşen bellek mekânları, Batı'nın durmayan işgalleriyle yok olmaktadır. Osmanlı Devleti ve tebaası, o yıllarda bir kaybının yasını tutamadan ona eklenen bir yenisinin etkisiyle kaotik bir ruh haline bürünmüş̧ür. Bunun en gerçekçi örneği, eserin kaleme alınmasından sadece birkaç yıl önce, Balkan savaşlarıyla Osmanlı'dan kopan büyük toprak parçası ve orada kimsesiz kalan insanların Anadolu'ya göçleridir. Zihinlerde meydana gelmesi istenen kıyam ve kendilik değerlerine dönüş, tarihin ibret verici imgeleminden faydalanarak gerçekleşecektir. Yalnızca artsüremli bir hatırlatma olmayan tarih bilinci, bireyi ve toplumu olumlu anlamda kuşattığı ve bilinç düzeyini zenginleştirdiği sürece temelleri sağlam bir düşünce dizgesi kurar. Mitat Durmuş'un deyimiyle; "tarih dediğimiz varlık alanı bir bilince evrildiğinde kendisini geçmiş zaman olmaktan çıarır." (Durmuş, 2017: 215). Böylelikle geçmiş ve gelecek ilişkisi zihinlerde yapıcı ve kurucu bir role evrilerek yarınların kurulmasında etkin rol oynar.

Geleceğe dair bir kurgusu ve hevesi kalmamış toplumlar kitlesel anlamda yıkıcı etkileri ölümcül derecelere varan bir depresyona kapılır ve umutsuzluğa gömülürler. Nizam-1 Âlem gibi büyük bir ülkü çerçevesinde şekillenen tarihselliğin karşısında şahit oldukları çağda büyük hezimetler yaşayan ve devletin eski ihtişamına duyulan özlemle daha da şiddetlenen endişe, bir atılımın değil; özgüven yitiminin, korkunun ve ümitsizliğin belirmesine yol açar. İşte şair bu noktada kutsal ve millî değerler dizgesiyle konuşarak uyanmayı ve sabahı aynı anlam çağrışımı içerisinde kullanır:

"Doğru mudur ye's ile olmak tebâh?

Yok mu gelip gayrete bir intibâh?

Beklediğin subh-1 kıyâmet midir?

Gu $\square$ n batıyor, sen ariyorsun sabâh!” (Ersoy, 1999: 307).

Doğru mudur?, yok mudur? gibi sözde soru ifadeleri farkındalık düzeyini arttırma ve uyarma amacıyla kullanılan ifadelerdir. Âkif, umutsuzluk sarmalında yıkıma doğru sürüklenen toplumu "yok mu gayrete bir intibah?" sorusuyla tahrik eder. "Âkif, miskinliğe karşı olduğu kadar ümitsizliğe de karşıdır. 1913'lü yıllar Osmanlı Devleti’nin asırlardır idare ettiği kavimler tarafından mağlup ve hatta 
perişân edildiği, dünkü ayakların baş olduğu Balkan Harbi yıllarıdır. İnanmış Âkif, bu kötü manzaralar karşısında ye'se kapılmaz ve imanı olan bir insanın ümitsizlik denizinde boğulamayacağını söyler.” (Yetiş, 1992: 119). Nafile bir arayış içerisindeki toplumun sabahı gün batımında araması tezadı, bilinç yitimi ve cehalete gönderme yapar. Köşesine çekilip ölümü bekleyen hasta gibi kıyamet sabahını bekler halde tasvir edilen topluma karşı seslenen şair, sabaha ulaşma konusundaki gayrete özlem duymaktadır.

Âkif, eserlerinde geçmişi bir ders alma, yarına sağlam bir biçimde ulaşmada faydalanılması gereken yaşanmışlıklar ve dersler bütünü olarak görür. Bunun yanı sıra geçmişe hapsolmak ve geçmiş zamanın ihtişamıyla övünerek yaratılan sanal gerçekliğin bugünü yok saymasına karşı çıkar. Toplumlar için tarihi anlamak ve tarihten ders almak; "geçmişten gelerek geleceği şekillendiren hayata şimdi'deki bilinç ile bakmak, şimdiye canlılık veren gerçek kuvvet ve kaynaklara işaret eder." (Deveci, 2017: 160). Bu kaynaklara sahip olan toplumlar, ellerindeki değerleri işleyerek yarınlarını daha müreffeh ve güvenli bir daire içerisinde kurabilirler. Avrupa'nın fikri ve sanayi alandaki ilerlemesine karş1 "dört yüz yıllık mutlak bir dünya hâkimiyetinin oluşturduğu aşırı kendine güven duygusuna" (Korkmaz, 2011: 17) kapılan Osmanlı Devleti'nin bu rehavetle iç dinamiklerini oluşturup güncellenmeyi gerçekleştirememesi ve çöküşü yaşaması gibi acı bir örneği de unutmayan şair, muhatabına "yarın"1 ve "yarın”ı kuracak nesilleri yetiştirmeyi ögütler. Ne var ki toplum hâlen geçmişe saplanıp kalmış, yarına dair bir kurgu üretmemiştir:

"Gözleri mâzîye bakan milletin

Ömru $\square$ temâdîsi olur nekbetin.

Karşına mu $\square$ stakbeli dikmiş Hudâ...

Görmeye lâkin daha yok niyyetin!” (Ersoy, 1999: 307).

Dörtlügün düşünsel temeli iki karşıt fikir üzerine inşa edilmiştir. Mazi ve müstakbel karşıtllğ 1 ile oluşturulan tartışma, ülkü değer olarak şairin kabulü olan müstakbel, toplumun tutulduğu hastalıkların yalnızca biri olarak karşıı değerler sınıfında konumlanan mazidir. Mazi, nekbet/felaket/talihsizlik sözcügüyle bir arada tutulurken gelecek ise Allah'ın sunduğu bir kutsal ihsan olarak verilir. Gözleri maziye bakmak, şairin, şiirin önceki birimlerinde de eleştirdiği umutsuzluk ve uyku halinin temel sebebidir. "Mehmet Âkif, Müslüman Türk mazisinin heyecanını benimsemekte, eski devirlerin saf ve temiz imanının özlemini çekmektedir. Bu ruhun milleti daha canlı olarak geleceğe bağlayacağına inanmıştır.” (Kocatürk, 2016: 700). Ne var ki karşısındaki toplum yalnızca bu devirlerin ihtişamının sarhoşluğuyla yetinmekle kalır. İstikbali kuracak, kendisini yenileyecek bir imkân silsilesini yalnızca geçici coşkunluk kaynağı olarak gören topluma, yüzyüze olduğu geleceği görmezden gelmesinden ötürü eleştiri oklarını doğrultur. Çünkü Âkif' in tasarladığ ideal birey, tarih şuuruna sahip, İslâmî değerlerle donanmış ve vatan sevgisini idrak etmiş, benliğinde toplumsal ve kolektif şuuru harmanlamış bir bireydir. Bir bakıma esere hâkim olan yüksek ton ve sitemkâr üslubun sebebi, bu donanıma sahip olmadığını gözlemlediği toplumdur denilebilir:

"Ey koca Şark, ey ebedî meskenet!

Sen de kımıldanmaya bir niyyet et.

Korkuyorum Garb'in elinden yarın,

Kalmayacak çekmediğin mel'anet." (Ersoy, 1999: 307).

Dörtlüğü oluşturan sözcük birimlerine bakıldığında Âkif, Şark ya da daha geniş ifadesiyle İslâm coğrafyasını, meskenet/miskinlik kavramlarıyla sefil bir halde tanımlarken; "aşırı özgüven içerisinde tembelleşen ve kötürümleşen milleti, sefalet sahneleri üzerinden sürekli eleştirir.” (Kanter, 2014: 221). Şark dünyasına sinmiş melanetin kaynağı Batı'dır. Modernleşme serüvenine dahil olma sürecine içerisinde bulunduğu tembellik ve aşırı özgüven sonucunda çok geç kalmış Osmanlı, bu

Turkish Studies - Language, 15(1) 
gecikmenin cezasını Batıdan gelen melanetlerle boğuşmak gibi bir bedel ile öder. Uzun yıllar hükmettiği Batı'nın yıkıcı uygulamaları ve trajik olaylar silsilesine dönüşen savaşlar neticesinde devlet darmadağın olmak üzeredir. Toplumsal anlamda Kımıldanmaya niyyet etmek ile başlayacak yaşamsal atılım kurtuluşun tek yoludur. Umutsuzca yapılan bu sesleniş batı karşısında zebun hale düşen İslâm toplumuna haykırıştır. Kendi değerleriyle ve varlık sahasının imkânlarıyla uyanacak olan toplumu düşleyen şairin bütün ümidi bu yönde görüntü bulacak bir canlanma/uyanma ve bilinçlenmededir.

Şair, eserin son dörtlüğünde topluma nihai seslenişini yapacaktır:

"Hakk-1 hayâtın daha çiğnenmeden,

Kan dökerek almalısın merd isen.

Çu $\square$ nku $\square$ bugu $\square$ n ortada hak sâhibi

Bir kişidir: 'Hakkımı vermem' diyen.” (Ersoy, 1999: 307).

Genel bir ifadeyle hale gönderme yaparak belirttiği çağ için, hakkı aramanın gerekliliğine dikkati çeken Âkif, yaklaşan millî mücadele yıllarını aydın bilinciyle fark edip toplumu önceden uyarır. Kendi içinde oturan ve kimliğini kazanan bireyler kendilik değerlerini iç dinamikleriyle kazanır ve bu kazanım köklü ve kutsal bir değer olarak nesilden nesile aktarılır. Üzerine odaklandığımız şiir metninin tamamında görülebilecek olan kolektif vicdanın sesi olma durumu bir aydın bilincinin gereği olarak Âkif' in eserlerinin tümünde vurgulu bir şekilde öne çıkmaktadır denilebilir. Şiirin geneline yayılmış olan ümitsizlik, yalnızca şaire etki etmemiştir. Karşısındaki "umutsuz" ve "uyku" halindeki toplumu, kendi değer dizgesiyle ayağa kaldırma amacındaki şair bir bakıma umudun ve geleceği kucaklamanın timsali olur.

\section{Sonuç}

Mehmet Âkif Ersoy'un Uyan adlı şiiri, içeriği ve göndergeleriyle şairin poetikasını belirleyen kavramları bütünüyle yansıtmakla beraber çăğın vicdanını temsil eden Âkif'in tarihsel ve toplumsal tavrıyla kolektif sesi sahiplendiği bir eserdir. Uyku ve problem yitimi gibi toplumsal hastalıkları ağır bir dille eleştiren şair, eleştirilerini çözüm önerileriyle tamamlar. Dönemini ve dönemin toplumsal yönelimini özetleyerek aydın bilincinin farkındalığıyla sorunları ortaya koyan şair, Safahat'ın genelinde görülebilecek üslubunu burada da koruyarak farkındalık yaratma ve uyarıcı amaçlı söylemiyle dikkat çekmeyi amaçlar. Toplumun karşı karşıya geldiği özgüven kaybı ve problem yitimine karşı köklerine ve dini değerlere dönüşle yeniden dirilişi ve uyanmayı arzulayan şair, bütün eseri seslendiği toplumun değerler dizgesine sadık kalarak inşa eder. Osmanlı toplumunun geleceği ile ilgili endişelerini anlatırken bir yandan da geleceğe ulaşmanın temel şartlarını, seslendiği kalabalığa içtenlikle aktarır. Eserin yazıldığı zaman dilimi göz önüne alındığında şairin sert üslubunun basit bir azarlama, toplumu küçümseme gibi daraltıcı tanımlamalardan uzak; geçmişi düşünsel ve devlet yönetimi anlamında yüksek bir seviye ve seciye bütünü olan toplumu özüne döndürme ve fikri anlamda uyku halinden tekrar ayağa kaldırma gayreti olduğu görülür. Mehmet Âkif Ersoy'un poetikasının bir özeti sayılabilecek şiir bu bağlamda gaflet, problem yitimi, bilinç felci ve özgüven eksikliği kavramlarının dikey boyuttaki mesajlarıyla örülerek toplumsal yönü öne çıkan bir eserdir. 


\section{Kaynakça}

Aktaş, Ş. (2005). Yenileşme Dönemi Türk Şiiri ve Antolojisi I. Ankara: Akçağ Yayınevi.

Alver, K. (2008). Mehmet Âkif Şiirinin Sosyo-Politiği Üzerine. Hece, Mehmet Âkif Özel Sayısı(133), 349-356.

Bilgegil, K. (1980). Yakın Çağ Türk Kültür ve Edebiyatı Üzerine Araştırmalar. Erzurum: Atatürk Üniversitesi Yayınları.

Deveci, M. (2017). Çanakkale Şehitlerine Şiiri Bağlamında Mehmet Âkifte Milli Kimlik İnşası. Çanakkale Ruhu ve Mehmet Âkif Ersoy (s. 153-167). Ankara: Kurgan Edebiyat.

Durmuş, M. (2017). Kişioğlunun Tarihsel Bir Sese Dönüşmesi Bağlamında Mehmet Akif Ersoy. Çanakkale Ruhu ve Mehmet Âkif Ersoy (s. 215-235). Ankara: Kurgan Edebiyat.

Eliuz, Ü. (2016). Kutsal Göstergeler Dizgesi: Çanakkale Şehitlerine. Çanakkale Ruhu ve Mehmet Âkif Ersoy (s. 63-83). Ankara: Berikan Yayınevi.

Ersoy, M. Â. (1912). Edebiyât. Sebîlürreşâd, 8(183), 10-11.

Ersoy, M. Â. (1999). Safahat. (M. E. Düzdağ, Dü.) İstanbul: Çağrı Yayınları.

Kanter, F. (2014). Milli Edebiyat Dönemi Türk şiirinde Benlik Alglsl ve Kimlik Kurgusu. İstanbul: Kitabevi.

Kaplan, M. (2003). Şiir Tahlilleri 1. İstanbul: Dergâh Yayınevi.

Kierkegaard, S. (2010). Ölümcül Hastalık Umutsuzluk. (M. M. Yakupoğlu, Çev.) Ankara: Doğu Batı Yayınlar1.

Kocatürk, V. M. (2016). Büyük Türk Edebiyatı Tarihi. İstanbul: İstanbul Kültür Üniversitesi Yayınevi.

Korkmaz, R. (2008). Aytmatov Anlatılarında Ötekileşme ve Dönüş İzlekleri. Ankara: Grafiker Yayıncilık.

Korkmaz, R. (2011). Yeni Türk Edebiyatı El Kitabı. Ankara: Grafiker Yayınları.

Okay, M. O. (2017). Mehmet Âkif: Kalabalıklarda Bir Yalnız Adam. İstanbul: Dergah Yayınları.

Sarıhan, Z. (1996). Mehmet Âkif. İstanbul: Kaynak Yayınları.

Timurtaş, F. K. (1987). Mehmet Âkif ve Cemiyetimiz. Ankara: Kültür ve Turizm Bakanlığı Yayınları.

Topçu, N. (2011). Mehmet Âkif. İstanbul: Dergah Yayınları.

Yetiş, K. (1992). Mehmet Âkif'in Sanat-Edebiyat ve Fikir Dünyasından Çizgiler. Ankara: Atatürk Kültür, Dil ve Tarih Yüksek Kurumu Yayınları.

Yetiş, K. (2006). Bir Mustarip Mehmet Âkif Ersoy. Ankara: Akçağ Yayınları. 